\title{
Pragmatic Steps towards Sustainable Development in the Economic Arena in Bangladesh
}

\author{
Mallika Roy ${ }^{1}$, Faria Hossain Borsha ${ }^{2}$ \\ ${ }^{1}$ (Lecturer in Economics), Faculty of Business Administration, BGC Trust University, Bangladesh) \\ ${ }^{2}$ (Teaching Assistant in Economics), Faculty of Business Administration, BGC Trust University, Bangladesh)
}

\begin{abstract}
Sustainable development has been pointed out as an indispensable condition to ensure a happy life for future generations in developing countries of the world. Also, it has been closely related to economic arena of those countries. Despite its significance, the issue cannot be done with solved easily as there are many factors that tend to debar its progress. In this regard, this paper aims to consider the multi-layered actuality of issues in the economic arena concerned with sustainable development in Bangladesh-the other two arenas being social and environmental. For this purpose, it examines the present scenario in the economic arena in Bangladesh, assesses the factors that influence the situation and comments on the strategies and tactics necessary to help development in Bangladesh become perennial. Through the above analysis, the paper clarifies the structures and tasks, as a whole in the issue of sustainable development in the economic field.
\end{abstract}

Keywords - Sustainable development, food security, poverty, agriculture, labor force, unemployment problem, income inequality, micro credit

\section{INTRODUCTION}

Emerging realities of globalization are changing the pattern of global economic relations. This aims at turning the unfolding scenario into national advantages towards building a sustainable future. Sustainable development vision is to build Bangladesh into a resilient, productive, innovative, and prosperous nation with a caring society consisting of healthy, happy, and well-educated people. Bangladesh has made good progress in major economic and social arena, particularly since the restoration of democracy, despite several challenges at home and externally including the adverse impact of global financial meltdown and recession, energy price hikes and the adverse effects of climate change. Bangladesh is rural based and has natural resources, but the problem is to allocate those resources effectively into the production process. This can only be made possible through a sustainable development process. Hence, sustainable development refers to the development activities that do not impair environmental resources or quality. This includes maintenance of an ecological balance, preservation of bio-diversity and protection of rare species and eco-systems.

\section{METHODOLOGY}

A major aim of this study is to draw a credible link between overall development progress and strategy options to the achievement. The emphasis on higher level results is intended to improve understanding of the outcome, its status, and the factors that contribute to change. There are also important lessons to be learned about how policy makers operate, opportunities and constraints they face, and effectiveness of the policy. This country evaluation, therefore, also includes "bottom-up" analyses of a sample of the most important factors.

The main evaluation was undertaken in two parts. The first mission was to evaluate current situation and the second mission was to identify the strategies which may be taken. Secondary data by several sources have been employed in this study. 


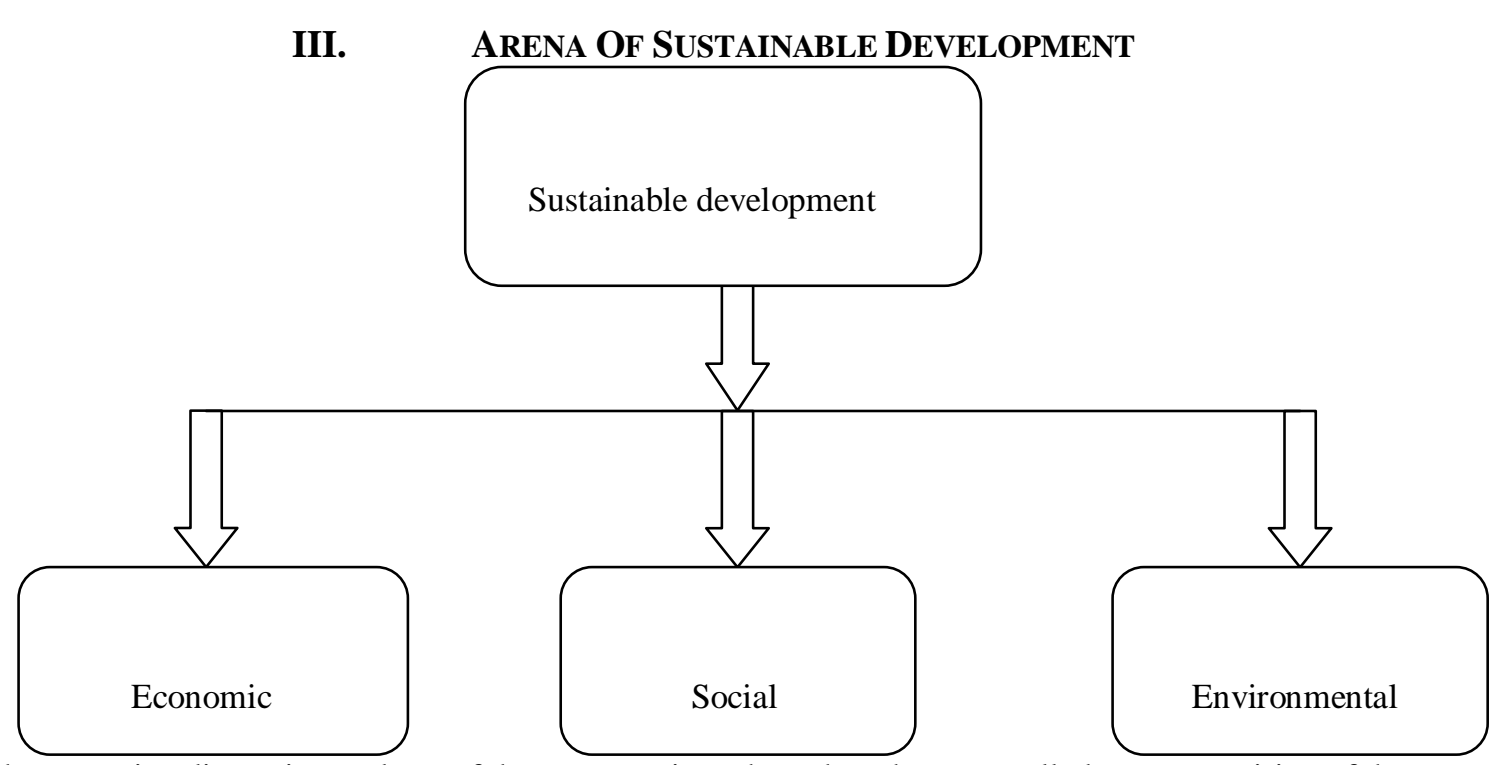

In the extensive discussion and use of the concept since then, there has generally been recognition of three aspects of sustainable development:

- Economic: An economically sustainable system must be able to produce goods and services on a continuing basis, to maintain manageable levels of government and external debt, and to avoid extreme sectoral imbalances which damage agricultural or industrial production.

- Environmental: An environmentally sustainable system must maintain a stable resource base, avoiding overexploitation of renewable resource systems or environmental sink functions, and depleting non-renewable resources only to the extent that investment is made in adequate substitutes. This includes maintenance of biodiversity, atmospheric stability, and other ecosystem functions not ordinarily classed as economic resources.

- Social: A socially sustainable system must achieve distributional equity, adequate provision of social services including health and education, gender equity, and political accountability and participation. Clearly, these three elements of sustainability introduce many potential complications to the original simple definition.

Today, the sustainable development "movement" is multidisciplinary and cross-sectoral. The movement brings together specialists from the physical and environmental sciences along with experts in development economics, political science, appropriate technology, human and women's rights, and others. [6]

Here, only the economic arena of sustainable development has been evaluated.

\subsection{Food Security}

\section{ECONOMIC ARENA}

Provision of food security is a constitutional obligation of Bangladesh. According to the world food summit (1996) "Food security exists when all people at all time, have physical economic access to sufficient, safe and nutritious food which meet their dietary needs and food preferences for an active and healthy life". Food security includes many issues ranging from food production to poverty status. In Bangladesh approximately half of the population lives in poverty. Seventy percent people live in rural area and draw their income and employment from agriculture and related activity. So, food security is closely related with agriculture and poverty.

This ongoing challenge has been compounded by the global food crisis, which in 2008 pushed more than 130 million people back into poverty as the price of staple foods rose by between 50 and 200 per cent. Prices abated somewhat in 2009, but since mid-2010 they have risen above even 2008 levels, pushing an estimated 44 million people back into poverty, according to the World Bank.

The Millennium Development Goal (MDG) 1 target to halve the proportion of people suffering from hungerfrom 20 per cent in 1990 to 10 per cent by 2015-remains off track.

Improving food security enables the poor to earn money and become more resilient which, in turn, enables them to participate in economic activity and contribute to social development

The overall goal of National Food Policy (NFP) is to ensure dependable food security for all people of the country at all times. Progress towards the NFP goal is monitored using three proxy indicator, they are

a. Undernourishment: The status of persons whose food intake regularly provides less then their minimum energy requirements

b. Underweight: 0 to 59 months-with using world health organization standards.

c. Stunting: 0 to 59 months. 
In this approach, the final out come of food security is improved nutrition of all, including the most vulnerable segment of the population. Thus adequate nutritional wellbeing is considered to be the only sufficient condition for food security. But adequate access and availability are seen as necessary but not sufficient condition to ensure food security. Agreed targets exist for the three indicators as the part of MDG and national planning processes .This targets are adopted for NFP monitoring. [7][10]

Table 1: National Food Policy (NFP) indicators relating to food security

\begin{tabular}{|l|l|l|l|l|l|l|}
\hline NFP indicator & $2007-08$ & $2008-09$ & $2009-10$ & $2010-11$ & Target 2015 & Source \\
\hline Undernourishment & $\begin{array}{l}26.8 \% \\
(2005-07)\end{array}$ & $\begin{array}{l}26.3 \%(2006- \\
08)\end{array}$ & $\begin{array}{l}25.8 \% \\
(2007-09)\end{array}$ & na & $19 \%$ (MDG-1) & $\begin{array}{l}\text { FAO, } \\
\text { SOFI }\end{array}$ \\
\hline underweight & $41 \%$ & na & na & $36 \%$ & $33 \%$ (MDG-1) & BDHS \\
\hline Stunting & $43 \%$ & na & na & $41 \%$ & $\begin{array}{l}38 \% \text { (revised } \\
2016 \text { HPNSDP } \\
\text { target) }\end{array}$ & BDHS \\
\hline
\end{tabular}

\subsection{Agriculture}

\subsubsection{Crop Sector}

The crop sector accounts for 12 percent of GDP. 60 percent of agricultural value addition comes from this sector. It occupies over three quarters of the cropped area. Rice production tripled from 11 million tones in 1972 to 32 million tons in 2009 (Outline Perspective Plan of Bangladesh 2010-2021; Planning Commission of Bangladesh). But rice import dependency has increased. Production of the other major crops like potato, vegetable has also increased.

Table-2: Domestic production (gross) trend of food grains, potato, pulses oilseeds, vegetables and fruits (199495 to 2004-05)

\begin{tabular}{|l|l|l|l|l|l|l|l|}
\hline \multirow{2}{*}{ Year } & Food grain & Potato & Pulses & Oilseeds & Vegetable & Fruit \\
\cline { 2 - 7 } & Rice & Wheat & & & & & \\
\hline $1994-95$ & 16833 & 1245 & 1468 & 535 & 480 & 1214 & 1414 \\
\hline $1995-96$ & 17687 & 1369 & 1492 & 524 & 471 & 1254 & 1431 \\
\hline $1996-97$ & 18880 & 1454 & 1508 & 525 & 478 & 1290 & 1418 \\
\hline $1997-98$ & 18862 & 1803 & 1553 & 518 & 482 & 1306 & 1403 \\
\hline $1998-99$ & 19905 & 1908 & 2762 & 499 & 476 & 1526 & 1359 \\
\hline $1999-2000$ & 23067 & 1840 & 2933 & 394 & 406 & 1529 & 1357 \\
\hline $2000-01$ & 25085 & 1673 & 3216 & 377 & 394 & 1472 & 1406 \\
\hline $2001-02$ & 24300 & 1606 & 2994 & 355 & 392 & 1599 & 1467 \\
\hline $2002-03$ & 25190 & 1507 & 3386 & 345 & 369 & 1605 & 1547 \\
\hline $2003-04$ & 26189 & 1253 & 4855 & 332 & 286 & 6133 & 1629 \\
\hline $2004-05$ & 25157 & 976 & 5948 & 527 & 566 & 7278 & 4600 \\
\hline
\end{tabular}

Table-3: Rice import dependency

\begin{tabular}{|l|l|l|l|l|}
\hline Indicator & $2007-08$ & $2008-09$ & $2009-10$ & $2010-11$ \\
\hline $\begin{array}{l}\text { Rice import dependency (imports/net } \\
\text { production +imports-exports); Three years } \\
\text { moving average. }\end{array}$ & $2.40 \%$ & $4.30 \%$ & $1.40 \%$ & $2.50 \%$ \\
\hline
\end{tabular}

Source:BBS

\subsubsection{Fisheries}

Fish product has increase rapidly since 1990s through pond aquaculture using hatchery reared fish fingerlings and conversion of fish pond by raising embankment around low laying land. However production under capture fisheries has stagnated because a under investment in fishing in the flood plains. The fish habitat in river, creeks and canals has been reduced steadily. Though shrimp is profitable, nature is getting disadvantage from it. Fish production has increase notably in Bangladesh. Table 4 enlightens the situation. 
Table 4: Progress in national fish production

\begin{tabular}{|l|l|l|l|l|l|}
\hline Indicator & $2007-08$ & $2008-09$ & $2009-10$ & $2010-11$ & \multicolumn{1}{|c|}{ Source } \\
\hline $\begin{array}{l}\text { Annual change in national Fish } \\
\text { production }\end{array}$ & $5.0 \%$ & $5.4 \%$ & $7.3 \%$ & $5.6 \%$ & $\begin{array}{l}\text { Fisheries Statiscal } \\
\text { Yearbook, DOF }\end{array}$ \\
\hline $\begin{array}{l}\text { GDP from fishery sector as \% of } \\
\text { agriculture GDP,(excluding forest) at } \\
\text { constant price 1995-1996 }\end{array}$ & $24.4 \%$ & $24.4 \%$ & $24.2 \%$ & $24.29 \%$ & $\begin{array}{l}\text { BBS Statistical } \\
\text { Yearbooks }\end{array}$ \\
\hline
\end{tabular}

\subsubsection{Livestock and Poultry}

There has been significant growth in the live stock sector. Much of it is coming from commercial poultry sector. The great increase in the demand for live stock product is caused by population, moderate growth of per capita income, and higher income elasticity of income. The demand for milk, egg and mutton has increased by $6,5.2$, and 5.6 percent respectively which is well above national average in the past. (Out line perspective plan of Bangladesh 2010-2021: planning commission of Bangladesh.). Table 5 shows us the scenario.

Table 5: Progress in Livestock and Poultry

\begin{tabular}{|c|c|c|c|c|c|}
\hline Indicator & $2007-08$ & $\begin{array}{l}2008- \\
09\end{array}$ & $2009-10$ & $2010-11$ & Source \\
\hline $\begin{array}{l}\text { GDP from livestock } \\
\text { sector } \\
\text { As \% of agricultural } \\
\text { GDP(Excluding } \\
\text { forest), at constant } \\
\text { price1995-96 }\end{array}$ & $14.6 \%$ & $14.5 \%$ & $14.4 \%$ & $14.1 \%$ & $\begin{array}{l}\text { BBS Statistical } \\
\text { Yearbook }\end{array}$ \\
\hline Eggs (million) & 5653 & 4692 & 5742 & 6079 & \multirow{3}{*}{$\begin{array}{l}\text { MoF, Bangladesh } \\
\text { Economic Review }\end{array}$} \\
\hline Milk(million MT) & 2.65 & 2.29 & 2.37 & 2.97 & \\
\hline Meat(million MT) & 10.4 & 1.08 & 1.26 & 1.99 & \\
\hline
\end{tabular}

The share of livestock value added on agriculture stuck slightly from $14.39 \%$ in $2009-10$ to 14.06 in 2010 11(Monitoring Report 2012; FPMU, food Division, Bangladesh ) confirming the movement observed since 2007 of a slow but continuous decline.

\subsection{Poverty}

BBS uses two different approaches to measure poverty: the direct calorie intake (DCI) method and the cost- of- basic- need (CBN) method. There have been different estimates on the level of poverty in Bangladesh. Poverty studies mainly concentrate on the measurement of poverty and the estimation of its magnitude. For this purpose, two methods are used to estimates poverty line, a) calorie intake and b) cost of basic needs (CBN) method. Two types of poor are distinguished under calorie intake, a) hard core poor; having less than 1,805 kcal per person per day and b) absolute poor; having less than 2,122 kcal per person per day. (GOB, 2001:55).

The CBN method constructs poverty line, which represent the level per capita expenditure at which the members of households can be expected to meet their basic needs, food and non-food. The allowance for nonfood consumption yields two poverty lines, a) lower, which incorporates a minimal allowance for non-food goods for those who could just afford the food requirement, and b) upper, which makes a generous allowance for non-food spending for those who just attain the food requirement (GOB, 2001:55-6). [1]

The alleviation of is a major development challenge and sustainable development is most crucial seen by the policy planner now a days. It is expected that sustainable poverty reduction will take place trough a tickle down economic growth. In present context the development objectives are increasing food production and perusing the export lead growth strategy. The World Bank supported the govt. primary objective to increase food grain production (World Bank 1990) [2]

A dedicated spotlight by successive government over the last 20 years has lead to a improvement in poverty situation. In terms of absolute numbers, in 2010, 47 million people were poor of which 26 million were extremely poor and 21 million were moderately poor. In 2005 these figure were 56million, 35million and 21 million respectively (Monitoring Report 2012; FPMU, Food Division, Bangladesh) so, after 2005 people live in extreme poverty is reduced by 9 million. Table 5 sheds light on the situation. 
Table: 6 Extreme poverty headcount index 2005 to 2010

\begin{tabular}{|l|l|l|l|}
\hline Indicator & 2005 & 2010 & Source \\
\hline $\begin{array}{l}\text { Extreme poverty Headcount index } \\
\text { (CBN lower poverty line) }\end{array}$ & $25.1 \%$ & $17.6 \%$ & $\begin{array}{l}\text { HIES Report } \\
\text { BBS }\end{array}$ \\
\hline $\begin{array}{l}\text { Poverty headcount index } \\
\text { (CBN upper poverty line) }\end{array}$ & $40.1 \%$ & $31.5 \%$ & $\begin{array}{l}\text { HIES Report } \\
\text { BBS }\end{array}$ \\
\hline
\end{tabular}

Though agricultural and poverty condition is improved, a large number of people disallowed from accessing food. Food security of the country has been significantly and harmfully affected by recent rising of food price .The countries food insecure people is now estimated to be 65.3 million people. Nearly $45 \%$ people of the country are now food insecure. And $23.9 \%$ of the population is understood as severely food insecure (World Food Program, 2005)

\subsection{Labor Force}

Labor force is defined as the active population of age 15+. This may be employed, under employed, self employed and unemployed, looking for gainful job. They may also be classified as skilled, semi skilled, and unskilled labor force. Active population below age 15 termed as child labor, is excluded from the labor force. Labor force is the key instrument to run the wheel of economy. It is observed from the table 7 that at the national level the man labor force had increased.

Table 7: Labor force 15+, 1995-2006

\begin{tabular}{|l|l|l|l|l|l|l|}
\hline \multirow{2}{*}{ Period } & National & Rural & Urban \\
\cline { 2 - 7 } & Women & Men & Women & Men & Women & Men \\
\hline $1995-1996$ & 5.4 & 30.6 & 3.8 & 23.9 & 1.6 & 6.7 \\
\hline $1999-2000$ & 8.6 & 32.2 & 6.4 & 25.1 & 2.2 & 7.1 \\
\hline $2002-2003$ & 10.3 & 35.0 & 7.7 & 27.3 & 2.7 & 8.6 \\
\hline $2005-2006$ & 12.1 & 37.3 & 9.3 & 28.4 & 2.8 & 8.9 \\
\hline
\end{tabular}

Source: Labor Force Survey, 2002-2003 and 2005-2006, BBS

\subsection{Unemployment Problem}

Unemployment incident is occurred when a person is failing to obtain a gainful job. Bangladesh is a small country with large population. Unemployment problem has become a severe problem now days.

Table 8: Unemployment rate of population, 2002-03 and 2005-06

\begin{tabular}{|c|c|c|c|c|c|c|}
\hline \multirow{2}{*}{$\begin{array}{l}\text { Year and } \\
\text { Area }\end{array}$} & \multicolumn{2}{|l|}{ Both sexes } & \multicolumn{2}{|l|}{ Men } & \multicolumn{2}{|l|}{ Women } \\
\hline & $\begin{array}{l}\text { No. of } \\
\text { Unemployed } \\
\text { Population } \\
(000) \\
\end{array}$ & $\begin{array}{l}\text { Unemployment } \\
\text { Rate }(\%)\end{array}$ & $\begin{array}{l}\text { No. of } \\
\text { Unemployed } \\
\text { Population } \\
(000)\end{array}$ & $\begin{array}{l}\text { Unemployment } \\
\text { Rate }(\%)\end{array}$ & $\begin{array}{l}\text { No. of } \\
\text { Unemployed } \\
\text { Population } \\
(000)\end{array}$ & $\begin{array}{l}\text { Unemployment } \\
\text { Rate }(\%)\end{array}$ \\
\hline \multicolumn{7}{|l|}{$2002-03$} \\
\hline Bangladesh & 2002 & 4.3 & 1500 & 4.2 & 502 & 4.9 \\
\hline Urban & 562 & 5.0 & 396 & 4.6 & 166 & 6.2 \\
\hline Rural & 1440 & 4.1 & 1101 & 4.0 & 336 & 4.4 \\
\hline \multicolumn{7}{|l|}{$2005-06$} \\
\hline Bangladesh & 2104 & 4.3 & 1250 & 3.4 & 954 & 7.0 \\
\hline Urban & 505 & 4.3 & 315 & 3.6 & 190 & 6.7 \\
\hline Rural & 1599 & 4.2 & 395 & 3.3 & 664 & 7.2 \\
\hline
\end{tabular}

Source: Labour Force Survey 2005-2006, BBS

Unemployment problem has a negative impact on social and economic factor. This is why every civilized government looks upon removal of unemployment as one of its primary duties. Generally there are three cause of unemployment namely
a. Under development
b. Inequitable distribution of national wealth
c. Over population

Employment generation is one of the means of addressing poverty in Bangladesh which has been suggested in the Poverty Reduction Strategy Paper. 
An employment strategy to accelerate poverty reduction must first and foremost aim to empower the poor. In every decade about 10 million labor force will be added due to increase in population and they need employment. [11]

\subsection{Income Inequality}

The last few decades witnessed a growing frustration with the perception of higher growth rate as the ultimate objective of all development activities. The development experience of last tow decades have shown that the benefit of higher growth rate trickled up rather then trickling down to the poor as traditionally believed. The HIES data suggest that inequality in the distribution of private per capita expenditure as measured by Gini coefficient, increased from 0.259 in $1991-92$ to 0.306 in 2000. Decay of national Gini coefficient by sector suggests that its increasing was due to not only to rising inequality within sectors but also to rising inequality between the urban and rural sectors.

Even the rich poor gap is alarmingly increasing day by day. For example the per capita income of the richest 5 percent of the population was 18 times the per capita income of the poorest 5 percent in 1991-93which have risen to 84 times by 2005 (www.perspectivebd.com). So, we can say that the rich poor gap is gradually increasing.

Primary report of household income and expenditure survey 2000 (World Bank, 2000) reveals that the top 5\% is gradually enjoying more resource while the income of lowest 5\% is reducing .In 1988-89 the top 5\% was enjoying $31.0 \%$ of the total income while in 2000 it stood up to $38.1 \%$. The lowest $5 \%$ on the other hand is enjoying $1.1 \%$ in $1988-89$ while it declined to $0.9 \%$ in 2000.

The rich saw a household income level rise of $13.36 \%$ while the poor found it decreasing by $3.56 \%$. The urban poor household income fell by $5.34 \%$ between $1999-04$ while the non Poor's income increased by $7.96 \%$.For the rural people, household income fell even deeper by $7.32 \%$. Rural non poor however saw a $3.23 \%$ rise (BBS; 2004).

A look at the per capita income shows that it increased by $17.51 \%$ at the national level. But the share of the poor in this growth was little. The growth of the Poor's income is $4.82 \%$ while non poor are witnessed $19.38 \%$ rise. The per capita income of the urban poor has been increased by $2.22 \%$ but it has been increased $11.54 \%$ for the non poor. At rural level it increased by $0.54 \%$ for the poor and $7.97 \%$ for the non poor (poverty monitoring survey report 2004; BBS)

\subsection{Micro credit:}

Micro credit has been introduced to rural communities in Bangladesh as a means of economic and social development. This country has become a testing ground for innovative micro-credit banking.

There are several micro-credit institutions, but two NGOs, BRAC and Grameen Bank have attracted the most publicity and study. Though male members initially had a significant presence, this gradually shifted in accordance with bank policy to female members.

The main goal of micro credit programs is to provide small loans in non-traditional economic sectors. A small amount of money can contribute a lot to poverty eradication, as attested to by the many successes, particularly amongst women, in villages and in remote areas. Thus, under micro credit system, all people will have the opportunity to satisfy their basic needs in an appropriate way, to have a say in the social and economic development process as it affects them and to participate in political decision making which helps to move towards sustainable development.

A successful micro credit program needs to fulfill three conditions: efficient resource distribution, self sufficiency and monitoring system. For maintaining a flexible repayment system, participating organization should limit such amount of each micro loan so that sufficient fund can reach in the hands of the poor.

From the 1970s through the 1990s, the number of people who obtained micro-credit grew from several thousand to about 10 million.

Micro credit loans have following characteristics:

1. The rate of repayment among the borrowers is quite high.

2. By micro credit institutions, the poor deposit money and these deposits strengthen the overall fund sufficiency.

3. This allows lenders to direct provide funds to people who are truly interested in working.

4. Micro credit can increase social and labor resources for the poor.

5. It can improve the infrastructure on a local level.

6. This strategy helps to the long term goal of creating economic opportunities.

Grameen bank's innovative design, open door loan policy, commitment to gender equality and its poverty alleviation potential has attracted interest from governments and international assistance agencies throughout the world. The Grameen Bank model is now being used as a reference in planning micro credit programs in other countries. [3],[4],[5],[12] 


\subsection{Food security:}

\section{Findings and Analysis}

Percentage of undernourishment, underweight and stunting was maximum in 2007-2008. On the other hand, percentage of underweight and stunting was minimum in 2010-2011. Again, percentage of undernourishment was minimum in 2009-2010.

\subsection{Agriculture:}

Rice production in 2002-2003 was maximum while the production was minimum in 1994-1995. We can see an increasing trend in rice production since 1995.But rice import dependency has increased. Production of wheat was highest in 1998-1999. On the other hand, wheat production was lowest in 2004-2005. The production amount of potato was maximum in 2004-2005 whereas potato production was minimum in 19941995.Ultimately, there is an increasing trend in 2004-2005. The amount of pulses production was highest in 1994-1995. Conversely, production of pulses was lowest in 2003-2004.Production of oilseeds was maximum in 2004-2005. But this production was minimum in 2003-2004. We can also see an increasing trend in oilseeds production. Production of vegetable was highest in 2004-2005 nevertheless it was lowest in 1994-1995. Fruit production was maximum in 2004-2005. Yet, the production was minimum in 1999-2000. Ultimately, it has a rising trend in fruit production. Annual change in national fish production was highest in 2009-2010 nonetheless it was lowest in 2007-2008. Ultimately, in 2010-11 it increased in comparison to in 2007-2008.Again, GDP from fisheries sector as percentage of agricultural GDP is maximum in 2007-2009, but it is minimum in 20092010.We can see that contribution to GDP from fisheries sector is decreasing in course of time.GDP from livestock sector as percentage of agricultural GDP was highest in 2007-2008 and was lowest in 20102011.Ultimately, we can see a decreasing trend.

Again, both egg and milk production was maximum in 2010-2011 and minimum in 2008-2009. On the other side, production of meat was maximum in 2007-2008 and minimum in 2008-2009. Thus, there are increasing trends in eggs and milk production and a decreasing trend in meat production.

\subsection{Poverty, Labor force and unemployment :}

The values of both the extreme poverty headcount index and poverty headcount index have fallen in 2010 compared to 2005.Labor force consisting of men and women countrywide, in rural and urban areas was minimum in 1995-1996. Conversely, it was maximum in 2005-2006. Unemployment rate of men has decreased in 2005-2006 and unemployment rate of women has increased in 2005-2006.

\subsection{Strategy for food security:}

\section{Strategies Recommended}

1. Further promoting intensification, sustainability and resilience of rice production in response to a rising demand in the context of high population and income growth.

2. Adjusting interventions to favor more diversified food production, including promotion of investments in processing and marketing.

3. Investments in agricultural research to tackle risks associated with climate change and promoting the valorization of unused land in coastal areas.

4. Updating/implementing policies on sustainable management of natural resources.

5. Facilitating agricultural mechanization in the context of increasing labor scarcity.

6. A more equitable growth pattern to accelerate food insecurity reduction.

7. Ensuring that poverty is also measured using the Direct Calorie Intake (DCI) method in the Household Income Expenditure Survey (HIES) so that food access in Bangladesh can be more accurately assessed.

8. Maximize the impact of poverty reduction on nutrition by integrating food security, livelihoods, social protection, health care practices and nutrition interventions.

9. Scale-up agricultural research funding to allow a 'technological breakthrough'.

10. Strengthen linkages among research, extension, education and farmers.

11. Modernize existing irrigation and water management systems and community participation.

\subsection{Strategy for agriculture:}

1. Yield gap for existing technology and better seeds must be reduced.

2. Alternate wet and dry irrigation, use of compost manure and direct seedling have to be focused.

3. Naturally favorable February- November may be used for growing high profit non rice crop.

4. High priority should be given to closed water fisheries production.

5. We have to emphasis on supply of inputs and promotion of technical knowledge among the educated youth, in pond and other close water bodies. 
6. For development of livestock production, poultry development and gradual growth in veterinary services and animal health must be ensured.

7. Govt. has to encourage breed development and marketing of livestock product.

8. Poverty eradication should be more highlighted.

\subsection{Strategy for poverty reduction}

1. People in Bangladesh may be encouraged to develop appropriate technologies that are indigenous in nature. Research should be carried out to further develop and improve these technologies. Indigenous technologies are found in different sectors such as cottage industries, forestry, poultry, fishery and dairy.

2. This country the potential of rural entrepreneurs are very high because of the availability of cheap raw material, abundant labor supply and simple and easily adaptable manual technology .Promotion of rural entrepreneurship can help alleviate poverty.

3. People have to make understand the importance of the surrounding environment.

4. Development of communication skill and a constructive attitude is essential.

5. We have to take proper step for agricultural non farm industrial development.

6. Human resource development must be enlightened.

7. Development of transportation has to be focused.

8. Market for agro commodities for both local and export markets should be developed.

\subsection{Strategy for reducing unemployment problem:}

In order to solve the problem the following measures may be effective.

1. Industrialization of our country can be a solution.

2. Vocational education should be introduced. Student must have to learn

about technical work.

3. We should learn to choose an independent career having due respect for manual labor.

4. Step should be made to increase overseas employment.

5. Government should be honest and sincere in their plans and policies.

\subsection{Strategy for reducing income inequality:}

1. Proper formulation and implementation of Monetary and Fiscal policy is very crucial to narrow the gap between rich and poor.

2. Fiscal policy is an important tool to affect the level of demand which in turn affect the level of employment.

3. Expansionist or a deflationary monetary policy may attempt to reduce unemployment and stimulate national economy

4. Creation of jobs shall narrow the gap between the poor and the rich.

5. The Government of Bangladesh should be put a serious emphasis to reduce poverty which would narrow the gap between rich and poor. Various safety net programmes can be an important instrument for this purpose.

\subsection{Strategy for micro credit:}

1. Micro credit program should be expanded.

2. The Government and Non-government Organizations should adopt new policies to provide micro finance in agricultural sector.

\section{Conclusion}

It cannot be said that economic arena of sustainable development is really very advanced in comparison to outcomes found in this arena in developed countries. The major barriers to improving economic arena appear to be in economic, social and cultural norms and the influence of the norms on them.

The article noted that if policy can be taken for reducing unemployment problem, poverty, income inequality and increasing agricultural production, micro credit program and GDP growth rate, the target to achieve sustainable development might be met.

The current situation over economic arena of sustainable development in Bangladesh may not be so strong, but when approached from multi-economic policies, the economic arena issue in Bangladesh will not remain unsolved. The economic arena, then, may improve at the optimum level. 
Journal papers:

\section{Reference:}

[1] Mahbuba Nasreen, Khondokar Mokaddem Hossain and Debasish Kumar Kundu, The Interrelationship between Poverty, Environment and Sustainable Development in Bangladesh: An Overview, PRSP and Environment, Poribesh (BAPA Newsletter), 4 th year, First issue, January-February, 2006.

[2] Shajeda Aktar, Growth, Poverty and Environmental linkage: Towards A Sustainable Development Strategy for Bangladesh, Pakistan Journal of Social Sciences 3 (4):648-660, 2005

[3] Solaiman Mohammed; Rahman Ataur (1999), An Account of the Sustainable Development Process In Bangladesh, sustainable development, Sust. Dev.7, 121-131

[4] Marc-Andre Roy, BSUS 6900, March $5^{\text {th }}, 2003$, Microfinance as a Tool for Development.

[5] Ross Mallick, Implementing and evaluating micro-credit in Bangladesh, Development in Practice, Volume 12, Number 2, May 2002

Working Paper:

[6] Jonathan M. Harris, Basic Principles of Sustainable development, working paper 00-04, Global Development and Environment Institute, June 2000

[7] Ministry of Food and Disaster Management, Government of the People's Republic of Bangladesh \& World Food Programme Bangladesh, Food Security in Bangladesh, 19-20 October 2005

Chapters in books:

[8] Statistical year book 2008, (Bangladesh Bureau of Statistics, Planning Division, Ministry of Planning, Government of the People's Republic of Bangladesh, Chapter-7, Page:85,111)

Thesis:

[9] Kazi Siam Ahmed, Economical Development of Bangladesh-Problems \& Solutions, Arcada University of Applied Sciences Report: International Business, Helsinki 2011,Page:19,20

[10] FPMU, Food Division, Ministry of Food and Disaster Management, Government of the People's Republic of Bangladesh, National Food Policy Plan of Action and Country Investment Plan, Monitoring Report 2012, July 2012, Page: 7,10,18,47

[11] NATIONAL SUSTAINABLE DEVELOPMENT STRATEGY (NSDS) BANGLADESH, Final Report , November 2008, Department of Environment, Ministry of Environment and Forests, Government of the People's Republic of Bangladesh,page:7

[12] The Importance of Micro-credit Programs in Sustainable Development, ICDF Annual Report 2002, Page: 171

\section{Web link:}

www.ausaid.gov.au/publications

www.perspectivebd.com

Source of data:

Bangladesh Demographic and Health Survey, 2007-2010

BBS; 2004

BBS 2007-2010

Food and Agriculture Organization, 2005-2009

Household Income and Expenditure survey report, 2005-2010

Poverty monitoring survey report, 2004; Bangladesh Bureau of Statistics.

Revised 2016 Health, Population and Nutrition Sector Development Program target

State of Food Insecurity, 2007-2010

World Bank, 2000; Primary report of household income and expenditure survey, 2000

World Food Program (2005), Food Security at a Glance 